\title{
Evaluation of Natural Radioactivity Levels and Potential Radiological Hazards of Common Building Materials Utilized in Mediterranean Region, Turkey
}

Şeref Turhan

Kastamonu Universitesi

Asli Kurnaz ( $\sim$ kurnazasli56@gmail.com )

Kastamonu Universitesi

Muhammet Karataşı

Beykent Üniversitesi: Beykent Universitesi

\section{Research Article}

Keywords: Building materials, Natural radioactivity, External and internal index, Activity Annual effective dose, Excess lifetime cancer risk

Posted Date: June 11th, 2021

DOI: https://doi.org/10.21203/rs.3.rs-500215/v1

License: (a) (1) This work is licensed under a Creative Commons Attribution 4.0 International License. Read Full License

Version of Record: A version of this preprint was published at Environmental Science and Pollution Research on September 15th, 2021. See the published version at https://doi.org/10.1007/s11356-02116505-7. 
Evaluation of natural radioactivity levels and potential radiological hazards of common building materials utilized in Mediterranean region, Turkey

\author{
Şeref Turhan ${ }^{1}$, Asli Kurnaz ${ }^{* 1}$, Muhammet Karataşl1² \\ ${ }^{1}$ Kastomunu University, Faculty of Science and Letters, Department of Physics, 37150 Kastamonu, Turkey \\ ${ }^{2}$ Beykent University, Faculty of Engineering and Architecture, Department of Electronics and Communication \\ Engineering, Sarıyer, İstanbul, Turkey
}

\begin{abstract}
Radiometric measurement of building materials is very important to assess the internal and external exposure caused by the ionizing radiation emitted from terrestrial radionuclides in building materials. The activity concentrations of ${ }^{226} \mathrm{Ra},{ }^{232} \mathrm{Th}$, and ${ }^{40} \mathrm{~K}$ in fifty-eight samples of fifteen different structural and covering building materials commonly used in Osmaniye province located in the Mediterranean region of Turkey were measured by using gamma-ray spectroscopy. The activity concentrations of ${ }^{226} \mathrm{Ra},{ }^{232} \mathrm{Th}$ and ${ }^{40} \mathrm{~K}$ varied from $2.5 \pm 0.1$ (marble) to $145.7 \pm 4.4$ (clay brick), $1.3 \pm 0.1$ (marble) to $154.3 \pm 4.1$ (marble) and $8.6 \pm 0.2$ (sand) to $1044.1 \pm 70.3$ (granite), respectively. Radiological parameters (activity concentration index, alpha index, indoor absorbed gamma dose rate and the corresponding annual effective dose rate, and excess lifetime cancer risk) were estimated to evaluate the
\end{abstract} health hazards associated with these building materials. Since the estimated values of these parameters are within the recommended safety limits or criteria values, the use of the studied building materials in the construction of dwellings can be considered to be safe for the residents of the region.

Keywords: Building materials; Natural radioactivity; External and internal index; Activity Annual effective dose; Excess lifetime cancer risk

\title{
Introduction
}

\footnotetext{
*Corresponding author: Tel.: +90 36628019 06; fax: +90 3662154969

E-mail address: kurnazasli56@gmail.com
} 
Human exposure to ionizing radiation emitted from natural radioactive sources (cosmic and terrestrial radionuclides) is an ongoing and unavoidable fact of life on earth (UNSCEAR 2008). In the UNSCEAR report, the value of worldwide average annual exposure (external and internal) to natural radiation sources was estimated as $2.4 \mathrm{mSv}$ (UNSCEAR 2008). The external exposure (indoor and outdoor) results from gamma-rays from terrestrial or primordial radionuclides such as radioactive potassium $\left({ }^{40} \mathrm{~K}\right)$ and the radioactive series of uranium $\left({ }^{238} \mathrm{U}\right)$ and thorium $\left({ }^{232} \mathrm{Th}\right)$. The concentrations of these radionuclides existing in all environmental media (soil, rock, food, water, building materials, etc.) may vary depending on the geological and geochemical structure of the region (UNSCEAR 2008). The average annual external exposure was assessed as $0.48 \mathrm{mSv}$, of which $0.41 \mathrm{mSv}$ is caused by indoor exposure (UNSCEAR 2008). The internal exposures come from the intake of terrestrial radionuclides by inhalation and ingestion (UNSCEAR 2008). The major contribution to the effective dose from inhalation is due to radon $\left({ }^{222} \mathrm{Rn}\right.$, half-life $\left.=3.83 \mathrm{~d}\right)$, which is the decay product of radium $\left({ }^{226} \mathrm{Ra}\right)$ in the ${ }^{238} \mathrm{U}$ series, and its short half-life decay products such as polonium $\left({ }^{218,214} \mathrm{Po}\right)$, lead $\left({ }^{214} \mathrm{~Pb}\right)$, and bismuth $\left({ }^{214} \mathrm{Bi}\right)$ (Turhan et al. 2018). The average annual inhalation exposure was assessed as $1.26 \mathrm{mSv}$, of which $1.15 \mathrm{mSv}$ is due to ${ }^{222} \mathrm{Rn}$ and $0.1 \mathrm{mSv}$ to thoron $\left({ }^{220} \mathrm{Rn}\right.$, half-life=55.6 s) (UNSCEAR 2008). Epidemiological surveys carried out in Europe, North America, and China have revealed strong evidence related to increased risk of lung cancer with high levels of radon exposure in dwellings (WHO 2009; Das 2021).

Building materials generally originated from the earth's crust (rocks and soil) can be divided into three categories: structural materials (cement, concrete, mortar, clay brick, pumice brick, etc.), covering materials used for insulation and ornamental purposes (marble, granite, andesite, tuff, gypsum plaster, etc.) and additive raw materials (blast furnace slag, fly ash, bauxite, phosphogypsum, etc.) obtained as a result of some industrial activities (Turhan et al. 2018). Building materials produced for permanent use used in the construction of 
dwellings, schools, and commercial buildings where we spend most of our time (approximately $80 \%$ lifetime), are one of the main sources of indoor external and internal exposures (Turhan et al. 2007; Joel et al. 2018). However, the radiation dose received from natural radionuclides in building materials depends on some conditions such as place and type of dwellings, ventilation habits, etc. Also, the activity concentrations of natural radionuclides in building materials vary depending on the geological and geochemical structure of the region where the materials are obtained (UNSCEAR 2008). Therefore, determination of natural radioactivity levels of building materials is very important in the evaluation of radiological hazards arising from indoor external and internal exposures to individuals and preparation standards and national guidelines of these materials in the light of international recommendations (Aykamış et al. 2013; Ravisankar et al. 2016). Recently, due to the increasing social anxiety, many studies on the measurement of natural radioactivity of different building materials and the assessment of the associated radiological risks on human health were published in the literature (Kumara et al. 2018; Al-Hubail and Al-Azmi 2018; Otoo et al. 2018; Leonardi et al. 2018; De With et al. 2018; Abdullahi et al. 2019; AlSewaidan 2019; Nuccetelli et al. 2020; La Verde et al. 2020; Orosun et al. 2020; Ghias et al. 2021). Up to now, several studies related to the determination of the activity concentrations of ${ }^{232} \mathrm{Th},{ }^{226} \mathrm{Ra}$, and ${ }^{40} \mathrm{~K}$ in some building materials used in Turkey and assessment of the radiological health hazards associated with these materials (Erees et al. 2006; Turhan et al. 2008; Turhan 2009; Mavi and Akkurt 2010; Turhan 2010; Turhan et al. 2011; Turhan and Varinlioğlu 2012; Baykara et al. 2012; Solak et al. 2014; Hatungimana et al. 2020). However, there is no detailed study related to the determination of the activity levels of terrestrial radionuclides in building materials utilized in Osmaniye province located in the Mediterranean region of Turkey and evaluation of radiological hazards associated with the utilization of these building materials. 

materials utilized in the construction of homes in Osmaniye province and evaluate their radiological consequence when used as building materials. In this study, the activity concentrations of ${ }^{226} \mathrm{Ra},{ }^{232} \mathrm{Th}$, and ${ }^{40} \mathrm{~K}$ in fifty-eight samples of fifteen different structural and covering and other building materials using gamma-ray spectrometry with an HPGe detector. The potential health hazards caused by the utilization of these materials were evaluated by estimating radiological parameters (external and internal, indoor absorbed gamma dose rate and the corresponding annual effective dose rate, and excess lifetime cancer risks). The obtained results were compared with the criterion values and/or recommended limits.

\section{Materials and method}

\section{Sample collection and preparation}

91 For this study, a total of fifty-eight building material samples given in Table 1 were purchased from commercial markets and manufacturers in Osmaniye province. Some of these materials are also widely used in other provinces in the Mediterranean region. Approximately $0.5 \mathrm{~kg}$ of each sample was brought to the sample preparation laboratory and coded. Then, the samples, except cement, sand, gypsum, grouting, and ceramic glue samples, were crushed and ground into a fine powder to have the same geometry as the reference materials used in detector efficiency calibration. Before radiometric measurement, all the crushed samples were passed through a sieve of $1 \mathrm{~mm}$ pore size and dried at $110{ }^{\circ} \mathrm{C}$ for $15-24 \mathrm{~h}$ to remove moisture content. Then each sample was transferred into a cylindrical polystyrene sample container

100 with a volume of $118 \mathrm{~mL}$, weighed, and hermetically sealed. Before counting, the sealed 101 samples were kept for at least one month to obtain secular equilibrium between ${ }^{226} \mathrm{Ra}$ and its decay products.

\section{Gamma-ray spectrometry}


104 Radiometric measurements of the building materials were conducted by using a high-

105 resolution gamma-ray spectrometry system with a coaxial p-type shielded HPGe detector

106 (GEM50P4-83) at the Central Research Laboratory of Kastamonu University, Turkey. Details

107 of the system are given in the study performed by Sultan et al. (2020). The detector has a

108 relative efficiency of $50 \%$, resolution of $1.9 \mathrm{keV}$ at a full-width half maximum (FWHM) for

$1091332.5 \mathrm{keV}$ gamma-ray photopeak ${ }^{60} \mathrm{Co}$ and peak to Compton ratio of $66: 1$. The efficiency

110 calibration of the system, which depends on parameters such as detector sample distance,

111 sample geometry, is determined using the equation given below (Solak et al. 2014):

$112 \varepsilon\left(E_{\gamma}\right)=\frac{C_{N e t}}{I_{\gamma} \cdot t_{C} \cdot A} \cdot f_{C} \cdot f_{G} \cdot f_{D}$

113 where $C_{N e t}$ is the net counts of gamma-ray photopeak of interest, $A$ is the activity of the

114 reference material (in $\mathrm{Bq}$ ), $I_{\gamma}$ is the emission probability of the gamma-ray of interest, $t_{C}$ is the

115 counting time in seconds, $f_{C}$ is the coincidence-summing correction factor, $f_{G}$ is the geometry

116 correction factor and $f_{D}$ is the decay correction factor. In this study, RGU-1 (U-ore; $400 \pm 2$

$\left.117 \mu \mathrm{g} \mathrm{g}^{-1}\right)$, RGTh-1 (Th-ore; $\left.800 \pm 16 \mu \mathrm{g} \mathrm{g}^{-1}\right)$ and RGK-1 $\left(\mathrm{K}_{2} \mathrm{SO}_{4} ; 44.8 \pm 0.3 \% \mathrm{~K}\right)$ reference

118 materials purchased from IAEA were used for efficiency calibration of the gamma-ray

119 spectrometer to eliminate the influence of coincidence summation and self-absorption effects

120 of the emitting gamma-ray photons (Stoulos et al. 2003; Sultan et al. 2020). First, these

121 reference materials were transferred to the sample containers to be used for measurement and

122 weighed. The containers with RGU-1 and RGTh-1 were then sealed to prevent the escape of

123 radon and thoron gases and kept for at least one month for secular radioactive equilibrium.

124 Each reference container placed on the top of the detector was counted for 5,000-10,000

125 seconds. The efficiency values obtained using the above formula for gamma-ray photopeaks

126 in the range of 0.2 to $2.6 \mathrm{MeV}$ were fit to the following function (Kurnaz et al. 2020):

$127 y\left(\varepsilon_{\gamma}\right)=\frac{1}{a+b \cdot x\left(E_{\gamma}\right)^{c}}$ 
128 where $E_{\gamma}$ is the energy of the gamma-ray photopeak and the $a, b$ and $c$ constants are equal to

$1294.64,0.0973$ and 0.899 , respectively.

\section{Radiometric measurement}

131 Each sample of building material studied was placed on the detector and counted for 40,000 -

13286,000 seconds to obtain good counting statistics. Background spectrum taken under the same

133 conditions was subtracted from the sample spectra to get net counts for the sample.

134 GammaVision gamma-ray spectroscopy software was used for spectrum analysis such as

135 peak searching, peak evaluation, nuclide identification, determination of uncertainty of peaks,

136 etc. The activity concentration of ${ }^{226} \mathrm{Ra}$ was determined using the weighted average of the

137 gamma-ray lines emitted from the progenies of ${ }^{226} \mathrm{Ra}\left(351.9 \mathrm{keV}\right.$ from ${ }^{214} \mathrm{~Pb}$ and 609.3 and

$138 \quad 1764.5 \mathrm{keV}$ from $\left.{ }^{214} \mathrm{Bi}\right)$. The activity concentration of ${ }^{232} \mathrm{Th}$ was determined using the

139 weighted average of the gamma-ray lines of $911.2 \mathrm{keV}$ from ${ }^{228} \mathrm{Ac}$ and $583.2 \mathrm{keV}$ from ${ }^{208} \mathrm{Tl}$.

140 The activity concentration of ${ }^{40} \mathrm{~K}$ was measured directly by its gamma-ray line at $1460.8 \mathrm{keV}$

141 (Kurnaz et al. 2020). The minimum detectable activity (MDA) based on Currie's derivation, at

142 the $95 \%$ confidence, is determined as follows:

$143 \quad \operatorname{MDA}\left(\mathrm{Bq} \mathrm{kg}^{-1}\right)=\frac{2.71+4.66 \sqrt{B}}{\varepsilon\left(E_{\gamma}\right) \cdot I_{\gamma} \cdot t_{C} \cdot M}$

144 where $B$ is the area of the background continuum under the gamma-ray line of interest, $\varepsilon(\mathrm{E} \gamma)$

145 is the efficiency calculated by Eq. (1) for the interested gamma-ray lines, and $M$ is the mass of

146 the sample (in $\mathrm{kg}$ ). The values of $M D A$ calculated for ${ }^{226} \mathrm{Ra},{ }^{232} \mathrm{Th}$ and ${ }^{40} \mathrm{~K}$ varied from 0.3 and

$1470.6 \mathrm{~Bq} \mathrm{~kg}^{-1}, 0.4$ to $0.7 \mathrm{~Bq} \mathrm{~kg}^{-1}$ and 5.2 to $7.1 \mathrm{~Bq} \mathrm{~kg}^{-1}$, respectively.

148 Evaluation of radiological hazards

149 Radiological parameters such as activity concentration index (external), alpha index (internal)

150 indoor absorbed gamma dose rate caused by the external exposure and the corresponding 
annual effective dose rate, and excess lifetime cancer risk were estimated to evaluate the

152 potential radiological hazards to human health associated with these building materials.

153 Preventive actions may be required for building materials with high annual effective dose

154 levels caused by external exposure due to gamma radiation emitted the radionuclides in

155 building materials where technologically enhanced naturally occurring radioactive materials

156 are used, such as fly ash, blast furnace slag, bauxite, phosphogypsum, Therefore the activity

157 concentration index based on the dose criterion was established by European Commission

158 (EC 1999) as a screening tool for identifying building materials that may be exempted or

159 subject to restrictions. The standard equation for the estimation of the activity concentration

160 index (I) is given below (EC 1999):

161

$$
I=\left(\frac{A_{R a}}{300 B q \mathrm{~kg}^{-1}}+\frac{A_{T h}}{200 B q \mathrm{~kg}^{-1}}+\frac{A_{K}}{3000 \mathrm{~Bq} \mathrm{~kg}}\right)
$$

162 where $A_{R a}, A_{T h}$ and $A_{K}$ are the activity concentration of ${ }^{226} \mathrm{Ra},{ }^{232} \mathrm{Th}$ and ${ }^{40} \mathrm{~K}$ in terms of $\mathrm{Bq} \mathrm{kg}^{-}$

$163{ }^{1}$, respectively. For structural materials such as cement, concrete, bricks when $\mathrm{I} \leq 1$, the

164 annual effective dose $\leq 1 \mathrm{mSv} \mathrm{y}^{-1}$ and while $\mathrm{I} \leq 0.5$ the annual effective $\leq 0.3 \mathrm{mSv}^{-1}$ (EC

165 1999). For covering and other materials limited use, when $\mathrm{I} \leq 6$, the annual effective dose $\leq 1$

$166 \mathrm{mSv} \mathrm{y}^{-1}$ and while $\mathrm{I} \leq 2$ the annual effective $\leq 0.3 \mathrm{mSv} \mathrm{y}^{-1}$ (EC 1999).

167 The alpha index $\left(I_{\alpha}\right)$ or internal health index, which is related to the assessment of excess $\alpha-$

168 radiation due to the inhalation of ${ }^{222} \mathrm{Rn}$ escaping from building materials, was calculated with

169 the formula given below (Solak et al. 2014):

$I_{\alpha}=\frac{A_{R a}}{200 B q k g^{-1}}$

171 If the activity concentration of ${ }^{226} \mathrm{Ra}$ in any building material exceeds a value of $200 \mathrm{~Bq} \mathrm{~kg}^{-1}$,

172 the ${ }^{222} \mathrm{Rn}$ exhalation may lead to indoor ${ }^{222} \mathrm{Rn}$ concentrations exceeding the recommended

173 level of $200 \mathrm{~Bq} \mathrm{~m}^{-3}$. Therefore, the value of $I_{\alpha}$ must be less than or equal to unity. 
174 Indoor absorbed gamma dose rate $\left(D_{R}\right.$ in terms of $\left.n G y \mathrm{~h}^{-1}\right)$ due to gamma-ray radiations

175 emitted from natural radionuclides $\left({ }^{226} \mathrm{Ra},{ }^{232} \mathrm{Th}\right.$, and $\left.{ }^{40} \mathrm{~K}\right)$ in the building materials was

176 estimated using the formula given by European Commission Report (EC 1999):

177 For the structural building materails:

$178 D_{R}=0.92 \cdot A_{R a}+1.10 \cdot A_{T h}+0.08 \cdot A_{K}$

179 For the covering building materails:

$180 \quad D_{R}=0.12 \cdot A_{R a}+0.14 \cdot A_{T h}+0.0096 \cdot A_{K}$

181 The corresponding annual effective dose rate $\left(E_{R}\right.$ in terms of $\left.\mathrm{mSv} \mathrm{y}^{-1}\right)$ was estimated using the

182 following formula (UNSCEAR 2000):

$183 E_{R}=D_{R} \cdot C_{F} \cdot O F \cdot T \cdot 10^{-6}$

184 where $D_{R}$ is the indoor absorbed gamma dose rate given in Eqs. (6) and (7), $C_{F}$ is dose

185 conversion factor $\left(0.7 \mathrm{~Sv} \mathrm{~Gy}^{-1}\right), O F$ is the indoor occupancy $(0.8)$ and $T$ is $8766 \mathrm{~h} \mathrm{y}^{-1}$.

186 Excess lifetime cancer risk $(E L C R)$, which gives the lifetime probability of cancer

187 development as a result of exposure to ionizing radiation, was estimated using the following

188 formula (Solak et al. 2014):

$189 \quad E L C R=E_{R} \cdot A L \cdot F_{R}$

190 where $E_{R}$ is the indoor annual effective dose rate given in Eq. (8), $A L$ is the average life (70 y)

191 and $F_{R}$ is the fatal risk factor $\left(0.057 \mathrm{~Sv}^{-1}\right)($ ICRP 1990).

192 Results and discussion

193 Table 2 presents the average and range (minimum-maximum) values of activity

194 concentrations of ${ }^{226} \mathrm{Ra},{ }^{232} \mathrm{Th}$, and ${ }^{40} \mathrm{~K}$ measured in the fifteen popularly used building

195 materials in the study area. Fig. 1 shows the frequency distributions (histograms) of the

196 activity concentrations of these radionuclides. A comparison of the average activity

197 concentrations of ${ }^{226} \mathrm{Ra},{ }^{232} \mathrm{Th}$, and ${ }^{40} \mathrm{~K}$ in the building material samples with Earth's crust

198 average values is given in Fig. 2. Table 3 compares the average activity concentration of these 
radionuclides measured in the studied some building material samples with the results of

200 similar studies reported in other countries.

201 It can be seen from Table 2 that the activity concentrations of radionuclides measured in the 202 building materials show a distribution that is directly related to the geology of their origin.

203 The activity concentrations of ${ }^{226}$ Ra varied from $2.5 \pm 0.1$ (in MARB sample) to $145.7 \pm 4.4$

204 (CBRICK sample) $\mathrm{Bq} \mathrm{kg}^{-1}$. The activity concentrations of ${ }^{232} \mathrm{Th}$ varied from $1.3 \pm 0.1$ (IMAT

205 sample) to $154.3 \pm 4.1$ (MARB sample) $\mathrm{Bq} \mathrm{kg}^{-1}$. The activity concentrations of ${ }^{40} \mathrm{~K}$ varied 206 from $8.6 \pm 0.4$ (SND sample) to $1044.1 \pm 70.3$ (GRNT sample) $\mathrm{Bq} \mathrm{kg}^{-1}$. As can be seen from

207 Fig. 1, the frequency distributions of the activity concentrations of ${ }^{226} \mathrm{Ra},{ }^{232} \mathrm{Th}$ and ${ }^{40} \mathrm{~K}$

208 measured in the studied building materials exhibit a log-normal distribution. Approximately

$20950 \%, 85 \%$ and $80 \%$ of the activity concentrations of ${ }^{226} \mathrm{Ra},{ }^{232} \mathrm{Th}$ and ${ }^{40} \mathrm{~K}$ are in the range of 3

210 to $35 \mathrm{~Bq} \mathrm{~kg}^{-1}, 1$ to $45 \mathrm{~Bq} \mathrm{~kg}^{-1}$ and 9 to $415 \mathrm{~Bq} \mathrm{~kg}^{-1}$, respectively. From Fig. 2, the average

211 activity concentration of ${ }^{226} \mathrm{Ra}$ measured in the building material samples, except for SND,

212 AGG, MARB and RTIL samples, is higher than the Earth's crust (worldwide) average value

213 of $32 \mathrm{~Bq} \mathrm{~kg}^{-1}$ (UNSCEAR, 2008). The average activity concentration of ${ }^{232} \mathrm{Th}$ measured in the

214 building material samples, except for CEM, MARB and GRNT samples, is lower than the

215 Earth's crust average value of $45 \mathrm{~Bq} \mathrm{~kg}^{-1}$ (UNSCEAR 2008). The average activity

216 concentration of ${ }^{40} \mathrm{~K}$ measured in the building material samples, except for GRNT sample, is

217 lower than the Earth's crust average value of $412 \mathrm{~Bq} \mathrm{~kg}^{-1}$ (UNSCEAR 2008). It can be seen

218 from Table 3 that the average concentrations of ${ }^{226} \mathrm{Ra}$ in the CEM, CBRICK, GYP, CONC,

219 and MARB samples are higher than those obtained for some other countries, except for

220 CONC utilized in European Union (EU) and MARB utilized in Greece, while the average

221 concentrations of ${ }^{226} \mathrm{Ra}$ in the SND and GRNT are lower than those obtained for some other

222 countries, expect for SND utilized in India (Polur) and GRNT utilized in Serbia and Iran

223 (Semnan). The average concentrations of ${ }^{232} \mathrm{Th}$ in the CEM and MARB samples are higher 
than those obtained for some other countries, except for CEM utilized in Bangladesh while

225 the average concentrations of ${ }^{232} \mathrm{Th}$ in the CONC and SAND are lower than those obtained for 226 some other countries. Also, the average concentrations of ${ }^{232} \mathrm{Th}$ in the CBRICK, GRNT, and GYP are comparable to those obtained for some other countries. The average concentrations of ${ }^{40} \mathrm{~K}$ in the CONC, SND, CBRICK, GRNT, and GYP are lower than those obtained for 229 some other countries, except for CBRICK utilized in Iran (Semnan), GRNT utilized in Serbia 230 and Iran (Semnan), and GYP utilized in Egypt.

231 The average and range values of the activity concentration index (I) and alpha index $\left(\mathrm{I}_{\alpha}\right)$

232 estimated for the studied building materials are given in Table 4. The values of I and $\mathrm{I}_{\alpha}$ varied 233 from 0.02 to 1.4 (GRNT sample) and 0.01 to 0.7 (CBRICK sample), respectively. All values

234 of I estimated for the structural materials don't exceed the recommended maximum or 235 criterion limit of unity corresponding to an annual effective dose rate of $1 \mathrm{mSv} \mathrm{y}^{-1}$ while all 236 values of I estimated for the covering and other materials with restricted use are lower than 237 the exemption level of 2 corresponding to an annual effective dose rate of $0.3 \mathrm{mSv} \mathrm{y}^{-1}$. All 238 values of $\mathrm{I} \alpha$ are lower than the recommended limit of unity corresponding to ${ }^{222} \mathrm{Rn}$ activity 239 concentration of $200 \mathrm{~Bq} \mathrm{~m}^{-3}$.

240 The average and range values of the indoor absorbed gamma dose rate $\left(D_{R}\right)$ and the 241 corresponding annual effective dose rate $\left(E_{R}\right)$, and excess lifetime cancer risk (ELCR) 242 estimated for the structural and covering building materials are given in Table 5. The values 243 of $D_{R}$ and $E_{R}$ varied from 1 (MARB sample) to 261 (CBRICK sample) $n G y h^{-1}$ and 0.003 to $2441.3 \mathrm{mSv} \mathrm{y}^{-1}$, respectively. The average values of $\mathrm{D}_{\mathrm{R}}$ estimated for CONC, SND, MARB, 245 GRN, and CTILE are below the world average indoor absorbed gamma dose rate of 84 nGy $246 \mathrm{~h}^{-1}$ (UNCCERA, 2000). The average values of $\mathrm{D}_{\mathrm{R}}$ estimated for CEM, CBRICK and PBRIC 247 are higher than \%45-61 higher than the world average value. All values of $E_{R}$ estimated for 248 the covering building materials are lower than the world average of $0.41 \mathrm{mSv} \mathrm{y}^{-1}$ (UNSCEAR 
2000). Furthermore, these values meet the exemption for the annual effective dose criterion

250 of $0.3 \mathrm{mSv} \mathrm{y}^{-1}$ recommended by the EU (EC 1999). The average values of $\mathrm{E}_{\mathrm{R}}$ estimated for

251 the structural building materials are higher than the world average of $0.41 \mathrm{mSv} \mathrm{y}^{-1}$ except for

252 CONC samples. Conversely, all average values meet the annual effective dose criterion of 1

$253 \mathrm{mSv} \mathrm{y}^{-1}$ recommended by EU (EC 1999). The average values of ELCR varied from $2.3 \times 10^{-4}$

254 to $2.3 \times 10^{-3}$. All average values of ELCR estimated for the structural and covering building

255 materials, except for MARB and CTILE are above the world average of $2.9 \times 10^{-4}$ due to the

256 annual effective dose rate caused by external exposure outdoor (UNSCEAR 2000). Whereas

257 the average ELCR values estimated for CEM, CBRICK, and PBRICK are higher than the

258 world average of $1.4 \times 10^{-3}$ due to the annual effective dose from indoor external exposure

259 (UNSCEAR 2000).

\section{Conclusions}

261 Determination of the activity concentration levels of the natural radionuclides contained in the

262 building materials utilized in the construction of dwellings, schools, and commercial

263 buildings is very important to evaluate the radiological risks associated with the utilization of

264 these materials. The activity concentrations of ${ }^{226} \mathrm{Ra},{ }^{232} \mathrm{Th}$, and ${ }^{40} \mathrm{~K}$ together with the

265 radiological parameters (activity concentration and alpha index, indoor absorbed gamma dose

266 rate and the corresponding annual effective dose rate, and excess lifetime cancer risk) for the

267 popularly utilized 58 building materials (6 structural and 9 covering and other materials) in

268 the Mediterranean region of Turkey, especially Osmaniye province was investigated using the

269 gamma-ray spectroscopy. The activity concentration results of these terrestrial radionuclides

270 reveal that there are significant differences in the measured values of building material

271 samples originating from different areas. This fact is important in choosing suitable materials

272 for utilization in buildings in the regions. It is concluded that all values of the activity

273 concentration and alpha index estimated for the studied building materials are lower than the 
274 criterion of unity. Also, all average values of the annual effective dose rate are below the

275 effective dose rate criterion of $1 \mathrm{mSv} \mathrm{y}^{-1}$ recommended by EU. Consequently, this study

276 reveals that the studied building material samples are within the recommended safety limit

277 and do not pose any significant source of radiation risks. The data obtained in this study is

278 significant in two respects: Firstly, it can create awareness for the local community using

279 these materials regarding the radioactivity that building materials may contain. Secondly, this

280 data is evaluated to be prepared standards and/or regulations regarding the use and

281 management of building materials utilized in Turkey.

\section{Author contribution}

283 M. Karataşl1 collected the building samples and prepared the samples for the radioactivity

284 measurements. A. Kurnaz and Ş. Turhan performed the laboratory measurements and

285 analyzed the spectra and done the spectra evaluations and the data analysis including the

286 statistical analysis. Ş. Turhan was a major contributor in writing the manuscript. All authors

287 read and approved the final manuscript.

\section{Funding}

289 Not applicable.

\section{Competing interests}

291 The authors declare no competing interests.

\section{Availability of data and materials}

293 All data generated or analyzed during this study are included in this published article anyway

294 datasets are available from the corresponding author on reasonable request.

\section{References}

296 Abdullahi S, Ismail AZ, Samat S (2019) Determination of indoor doses and excess lifetime cancer risks caused by building materials containing natural radionuclides in Malaysia. 
Aladeniyi K, Arogunjo AM, Pereira AJSC, Khandaker MU, Bradley DA, Sulieman A (2021) Evaluation of radiometric standards of major building materials used in dwellings of South-Western Nigeria. Radiat Phys Chem 178(109021):1-9

Al-Hubail J, Al-Azmi D (2018) Radiological assessment of indoor radon concentrations and gamma dose rates in secondary school buildings in Kuwait. Constr Build Mater $183: 1-6$

Al-Sewaidan HA (2019) Natural radioactivity measurements and dose rate assessment of selected ceramic and cement types used in Riyadh, Saudi Arabia. J King Saud Univ Sci 31:987-992

Asaduzzaman K, Mannan F, Khandaker MU, Farook MS, Elkezza A, Amin YM, Sharma S, Kassim HA (2015) Assessment of natural radioactivity levels and potential radiological risks of common building materials used in Bangladeshi dwellings. PloS One 10(10):1-16

Aykamış AŞ, Turhan Ş, Uğur FA, Baykan UN, Kılıç AM (2013) Natural radioactivity, radon exhalation rates and indoor radon concentration of some granite samples used a construction material in Turkey. Radiat Prot Dosim 157:105-111

Baykara O, Karatepe S, Doğru M (2012) Assessments of natural radioactivity and radiological hazards in construction materials used in Elazig, Turkey. Radiat Meas 46(1):153-158

Das B (2021) Radon induced health effects: A survey Report. Indian J Sci Technol 4(5):481507

De With G, Michalik B, Hoffmann B, Döse M (2018) Use of NORM-containing products in construction development of a European harmonised standard to determine the natural radioactivity concentrations in building materials. Constr Build Mater 171:913-918 
EC (European Commission) (1999) Radiation Protection 112- Radiological Protection Principles Concerning the Natural Radioactivity of Building Materials. DirectorateGeneral Environment, Nuclear Safety and Civil Protection

Erees FS, Dayanıklı SA, Çam S (2006) Natural radionuclides in the building materials used in Manisa city, Turkey. Indoor Built Environ 15(5): 495-498

Ghias S, Satti KH, Khan M, Dilband M, Naseem A, Jabbar A, Kali S, Rehman TU, Nawab J, Aqeel M, Khan MA, Zafar MI (2021) Health risk assessment of radioactive footprints of the urban soils in the residents of Dera Ghazi Khan, Pakistan. Chemosphere 2671(29171):1-14

Hatungimana D, Taşköprü C, İçhedef M, Saç MM, Yazıcı Ş, Aghabaglou AM (2020) Determination of radon and natural radioactivity concentration in some building materials used in İzmir, Turkey. J Green Build 15(1):107-118

ICRP (1990) Recommendations of the International Commission on Radiological Protection. Vol. 212 No.1-3, publication 60

Imani M, Adelikhah M, Shahrokhi A, Azimpour G, Yadollahi A, Kocsis E, Toth-Bodrogi E, Kovács T (2021) Natural radioactivity and radiological risks of common building materials used in Semnan Province dwellings, Iran. Environ Sci Pollut Res https://doi.org/10.1007/s11356-021-13469-6

Joel ES, Maxwell O, Adewoyin OO, Ehi-Eromosele CO, Embong Z, Saeed MA (2018) Assessment of natural radionuclides and its radiological hazards from tiles made in Nigeria. Radiat Phys Chem 144:43-47

Kumara PARP, Mahakumara P, Jayalath A, Jayalath CP (2018) Estimating natural radiation exposure from building materials used in Sri Lanka. J Radiat Res Appl Sci 11:350_ 354 
Kurnaz A, Turhan Ş, Hançerlioğulları A, Gören E, Karataşı M, Altıkulaç A, Erer AM, Metin O (2020) Natural radioactivity, radon emanating power and mass exhalation rate of environmental soil samples from Karabük province, Turkey. Radiochimica Acta 108(7):573-579

Kuzmanović P, Todorović N, Petrović LF, Mrđa D, Forkapić S, Nikolov J, Knežević J (2020) Radioactivity of building materials in Serbia and assessment of radiological hazard of gamma radiation and radon exhalation. J Radioanal Nucl Chem 324:1077-1087

La Verde G, Raulo A, D’Avino V, Roca V, Pugliese M (2020) Radioactivity content in natural stones used as building materials in Puglia region analysed by high resolution gamma-ray spectroscopy: Preliminary results. Constr Build Mater 239(117668):1-6

Leonardi F, Bonczyk M, Nuccetelli C, Wysocka M, Michalik B, Ampollini M, Tonnarini S, Rubin J, Niedbalska K, Trevisi R (2018) A study on natural radioactivity and radon exhalation rate in building materials containing norm residues: preliminary results.

Nuccetelli C, Leonardi F, Trevisi R (2020) Building material radon emanation and exhalation rate: Need of a shared measurement protocol from the European database analysis. $\mathbf{J}$

Mavi B, Akkurt I (2010) Natural radioactivity and radiation hazards in some building Environ Radioact 225(106438):1-7 materials used in Isparta, Turkey. Radiat Phys Chem 79:933-937

Orosun MM, Usikalu MR, Oyewumi KJ, Achuka JA (2020) Radioactivity levels and transfer factor for granite mining field in Asa, North-central Nigeria. Heliyon 6:1-6

Otoo F, Darko EO, Garavaglia M, Giovani C, Pividore P, Andam AB, Amoako JK, Adukpo OK, Inkoom S, Adu S (2018) Public exposure to natural radioactivity and radon exhalation rate in construction materials used within Greater Accra Region of Ghana. Scientific African 1:1-12 
Pantelić GK, Todorović DJ, Nikolić JD, Rajačić MM, Janković MM, Sarap NB (2015) Measurement of radioactivity in building materials in Serbia. J Radioanal Nucl Chem $303: 2517-2522$

Ravisankar R, Raghu Y, Chandrasekaran A, Gandhi MS, Vijayagopal P, Venkatraman B (2016) Determination of natural radioactivity and the associated radiation hazards in building materials used in Polur, Tiruvannamalai District,Tamilnadu, India using gamma ray spectrometry with statistical approach. J Geochem Explor 163:41-52

Shoeib MY, Thabayneh KM (2014) Assessment of natural radiation exposure and radon exhalation rate in various samples of Egyptian building materials. J Radiat Res Appl Sc 7:174-181

Solak S, Turhan Ş, Uğur FA, Gören E, Gezer F, Yeğingil Z, Yeğingil İ (2014) Evaluation of potential exposure risks of natural radioactivity levels emitted from building materials used in Adana, Turkey. Indoor Built Environ 23(4): 594-602

Sultan DAO, Turhan Ş, Kurnaz A, Hançerlioğulları A, Kamberli AK, Emeksizoğlu B (2020) Investigation of natural radionuclide and essential metal contents of ancient wheat einkorn (Triticum monococcum L.) grown in Turkey. Radiochim Acta 108:999-1007

Stoulos S, Manolopoulou M, Papastefanou C (2003) Assessment of natural radiation exposure and radon exhalation from building materials in Greece. J Environ Radioact 69:225240

Trevisi R, Risica S, D’Alessandro M, Paradiso D, Nuccetelli C (2012) Natural radioactivity in building materials in the European Union: a database and an estimate of radiological significance. J Environ Radioact 105:11-20.

Tuo F, Peng X, Zhou Q, Zhang J (2020) Assessment of natural radioactivity levels and radiological hazards in building materials. Radiat Prot Dosim 188(3):316-321 
Turhan Ş, Yücel H, Gündüz L, Şahin Ş, Vural M, Parmaksız A, Demircioglu B (2007) Natural radioactivity measurement in pumice samples used raw materials in Turkey. Appl Radiat Isot 65:350-354

Turhan Ş, Baykan UN, Şen K (2008) Measurement of the natural radioactivity in building materials used in Ankara and assessment of external doses. J Radiol Prot 28:83-91

Turhan Ş (2009) Radiological impacts of the usability of clay and kaolin as raw material in manufacturing of structural building materials in Turkey. J Radiol Prot 29:75-83

Turhan, S. 2010. Radioactivity levels of limestone and gypsum used as building raw materials in Turkey and estimation of exposure doses. Radiat. Prot. Dosim. 140(4), 402-407.

Turhan Ş, Arıkan İH, Demirel H, Güngör N (2011) Radiometric analysis of raw materials and end products in the Turkish ceramics industry. Radiat Phys Chem 80(5): 620-625

Turhan Ş, Varinlioğlu A (2012) Radioactivity measurement of primordial radionuclides in and dose evaluation from marble and glazed tiles used as covering building materials in Turkey. Radiat Prot Dosim151(3):546-555 Turhan Ş, Temirci AT, Kurnaz A, Altıkulaç A, Gören E, Karataşlı M, Kırışık R, Hançerlioğulları A (2018) Natural radiation exposure and radon exhalation rate of building materials used in Turkey. Nucl Technol Radiat Prot 33(2):159-266 UNSCEAR (United Nations Scientific Committee on the Effects of Atomic Radiation) 2008 (2010) Sources and Effects of Ionizing Radiation. United Nations Scientific USA UNSCEAR (United Nations Scientific Committee on the Effects of Atomic Radiation) (2000) 

perspective edited by Hajo Zeeb, and Ferid Shannoun. WHO Library

\section{FIGURE CAPTIONS}

436 Fig. 1

437 Frequency distributions of the activity concentrations of radionuclides in the studied building 438 materials

439 Fig. 2

440 Comparison of the average values of radionuclides measured in the studied building materials 441 with those in the Earth's crust 


\section{TABLE CAPTIONS}

446 Table 1

447 Building materials of different types utilized in Osmaniye province

448 Table 2

449 The activity concentrations of ${ }^{226} \mathrm{Ra},{ }^{232} \mathrm{Th}$, and ${ }^{40} \mathrm{~K}$ measured in the studied building material

450 samples

$451 \quad$ Table 3

452 Comparison of radioactivity concentrations measured in this study with those in building

453 materials utilized in other countries

454 Table 4

455

456 The values of activity concentration index and alpha index

457 Table 5

458 The values of the indoor absorbed gamma dose rate, annual effective dose, and excess

459 lifetime cancer risk

460

461

462

463

464

465

466

467

468

469 

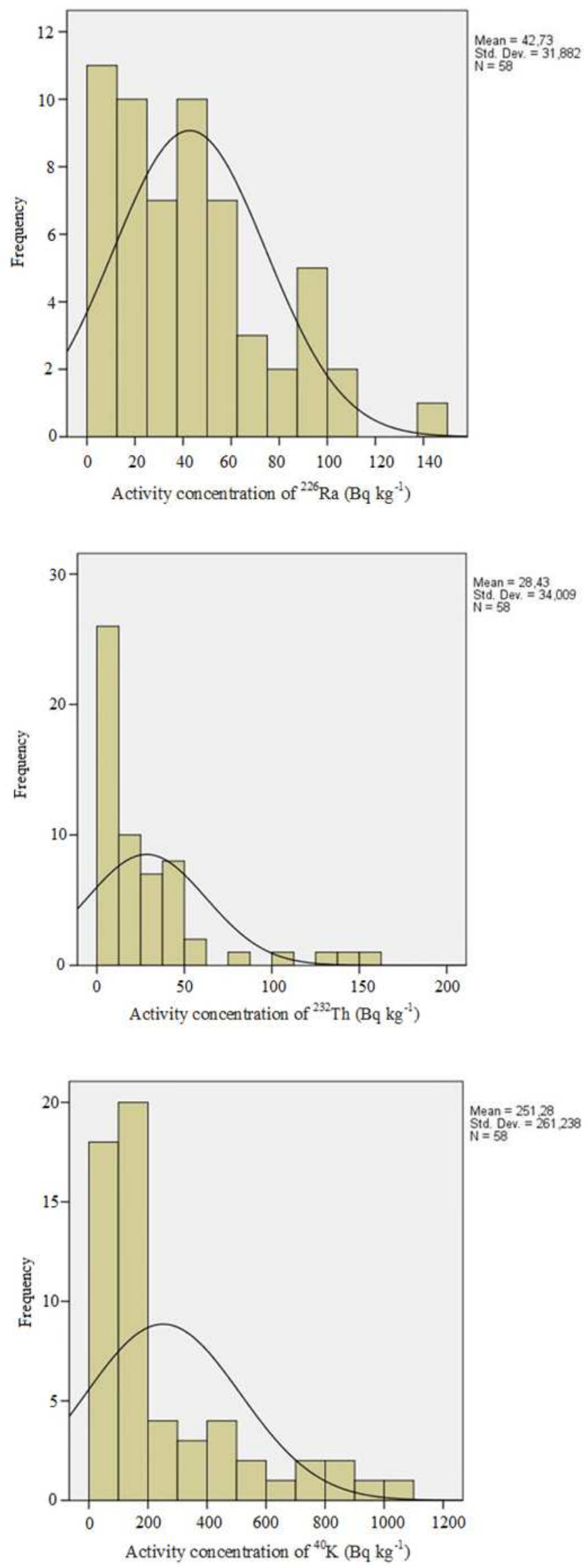

Fig. 1 


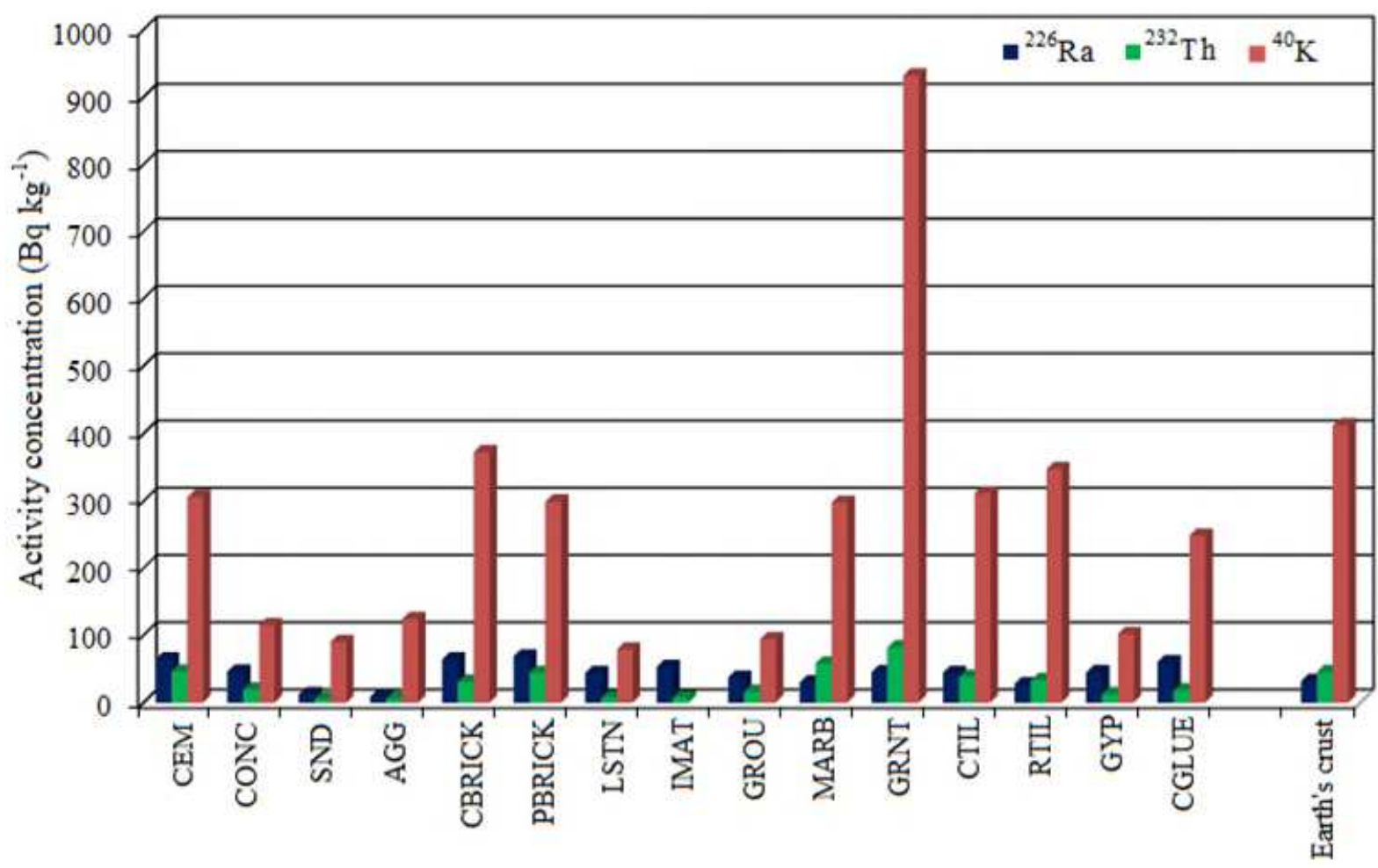

471

Fig. 2

472

473

474

475

476

477

478

479

480

481

482

483

484

485

486 


\begin{tabular}{llll}
\hline Type & Building material & Sample ID & N \\
\hline & Cement & CEM & 5 \\
\multirow{4}{*}{$\begin{array}{l}\text { Structural materials used in } \\
\text { bulk amounts }\end{array}$} & Concrete & CONC & 3 \\
& Clay brick & CBRCK & 4 \\
& Pumice brick & PBRCK & 3 \\
& Sand & SND & 5 \\
& Aggregate & AGG & 4 \\
\hline \multirow{5}{*}{ Covering and other } & Marble & MARB & 5 \\
materials with restricted & Granite & GRNT & 3 \\
& Ceramic tile & CTIL & 5 \\
& Roofing tile & RTIL & 3 \\
& Gypsum & GYP & 5 \\
& Limestone & LSTN & 2 \\
& Insulating material & IMAT & 3 \\
& Grouting & GROU & 3 \\
& Ceramic glue & CGLUE & 5 \\
\hline
\end{tabular}

487

488 Table 1

489

490

491

492

493

494

495

496

497

498

499

500

501

502

503

504

505

506

507

508

509

510 


\begin{tabular}{|c|c|c|c|c|}
\hline \multirow{2}{*}{$\begin{array}{l}\text { Sample } \\
\text { ID }\end{array}$} & & \multicolumn{3}{|c|}{ Activity concentration $\left(\mathrm{Bq} \mathrm{kg}^{-1}\right)$} \\
\hline & & ${ }^{226} \mathrm{Ra}$ & ${ }^{232} \mathrm{Th}$ & ${ }^{40} \mathrm{~K}$ \\
\hline \multirow[t]{2}{*}{ CEM } & Average & 63.7 & 46.2 & 306.2 \\
\hline & Range & $11.8 \pm 0.4-91.4 \pm 2.7$ & $12.1 \pm 0.3-112.3 \pm 3.1$ & $135.5 \pm 7.2-423.7 \pm 23.8$ \\
\hline \multirow[t]{2}{*}{$\mathrm{CONC}$} & Average & 46.4 & 19.0 & 115.0 \\
\hline & Range & $13.4 \pm 0.3-65.7 \pm 1.8$ & $12.3 \pm 0.3-29.3 \pm 0.6$ & $48.1 \pm 2.4-222.6 \pm 13.5$ \\
\hline \multirow[t]{2}{*}{ CBRICK } & Average & 63.5 & 30.8 & 372.3 \\
\hline & Range & $18.8 \pm 0.5-45.7 \pm 4.4$ & $4.6 \pm 0.1-55.2 \pm 1.5$ & $53.5 \pm 2.4-821.9 \pm 60.1$ \\
\hline \multirow[t]{2}{*}{ PBRIK } & Average & 67.6 & 44.0 & 298.7 \\
\hline & Range & $42.7 \pm 1.1-95.4 \pm 2.8$ & $41.0 \pm 1.3-46.8 \pm 1.4$ & $110.6 \pm 5.4-493.6 \pm 36.8$ \\
\hline \multirow[t]{2}{*}{ SND } & Average & 12.3 & 4.9 & 90.0 \\
\hline & Range & $8.6 \pm 0.2-20.2 \pm 0.5$ & $1.8 \pm 0.1-7.7 \pm 0.2$ & $8.6 \pm 0.4-157.7 \pm 7.1$ \\
\hline \multirow[t]{2}{*}{ AGG } & Average & 8.7 & 6.3 & 123.7 \\
\hline & Range & $7.4 \pm 0.2-9.5 \pm 0.3$ & $6.2 \pm 0.2-6.5 \pm 0.2$ & $118.2 \pm 5.2-134.3 \pm 6.7$ \\
\hline \multirow[t]{2}{*}{ MARB } & Average & 30.3 & 57.9 & 296.7 \\
\hline & Range & $2.5 \pm 0.1-89.1 \pm 2.3$ & $1.3 \pm 0.1-154.3 \pm 4.1$ & $12.7 \pm 0.7-857.3 \pm 62.4$ \\
\hline \multirow[t]{2}{*}{ GRNT } & Average & 45.4 & 82.3 & 931.6 \\
\hline & Range & $13.4 \pm 0.4-103.0 \pm 2.8$ & $46.5 \pm 1.4-141.9 \pm 3.7$ & $784.0 \pm 42.5-1044.1 \pm 70.3$ \\
\hline \multirow[t]{2}{*}{ CTILE } & Average & 43.5 & 37.9 & 310.9 \\
\hline & Range & $9.6 \pm 0.3-102.6 \pm 2.7$ & $8.9 \pm 0.2-77.0 \pm 2.0$ & $41.9 \pm 3.9-641.7 \pm 50.6$ \\
\hline \multirow[t]{2}{*}{ RTILE } & Average & 27.0 & 32.6 & 346.6 \\
\hline & Range & $18.9 \pm 0.4-36.6 \pm 0.9$ & $22.9 \pm 0.5-39.2 \pm 1.1$ & $65.6 \pm 3.5-505.6 \pm 30.2$ \\
\hline \multirow[t]{2}{*}{ GYP } & Average & 44.5 & 11.9 & 101.5 \\
\hline & Range & $26.5 \pm 0.8-53.4 \pm 1.6$ & $5.6 \pm 0.2-26.2 \pm 0.8$ & $53.5 \pm 2.8-128.9 \pm 7.9$ \\
\hline \multirow[t]{2}{*}{ LSTN } & Average & 44.2 & 7.2 & 78.9 \\
\hline & Range & $38.9 \pm 1.2-49.4 \pm 1.5$ & $5.1 \pm 0.1-9.3 \pm 0.3$ & $61.2 \pm 3.7-96.5 \pm 5.6$ \\
\hline \multirow[t]{2}{*}{ IMAT } & Average & 52.6 & 7.1 & 118.0 \\
\hline & Range & $17.7 \pm 0.5-97.8 \pm 2.9$ & $1.3 \pm 0.1-16.8 \pm 0.5$ & $66.0 \pm 3.4-183.0 \pm 9.7$ \\
\hline \multirow[t]{2}{*}{ GROU } & Average & 37.1 & 15.5 & 94.0 \\
\hline & Range & $15.3 \pm 0.4-53.2 \pm 1.6$ & $9.1 \pm 0.2-20.7 \pm 0.6$ & $41.4 \pm 2.1-168.6 \pm 9.5$ \\
\hline \multirow[t]{2}{*}{ CGLUE } & Average & 60.2 & 18.1 & 247.8 \\
\hline & Range & $37.2 \pm 1.1-97.3 \pm 2.9$ & $6.3 \pm 0.2-25.8 \pm 0.7$ & $95.8 \pm 7.1-709.9 \pm 40.2$ \\
\hline
\end{tabular}

514

515 Table 2

516

517

518

519

520 


\begin{tabular}{|c|c|c|c|c|c|}
\hline \multirow[t]{2}{*}{ Building material } & \multirow[t]{2}{*}{ Country } & \multicolumn{3}{|c|}{ Activity concentration $\left(\mathrm{Bq} \mathrm{kg}^{-1}\right)$} & \multirow[t]{2}{*}{ Reference } \\
\hline & & ${ }^{226} \mathrm{Ra}$ & ${ }^{232} \mathrm{Th}$ & ${ }^{40} \mathrm{~K}$ & \\
\hline \multirow{9}{*}{ Cement } & Nigeria & 21 & 16 & 147 & Aladeniyi et al. 2021 \\
\hline & Iran (Semnan) & 31 & 15 & 231 & Imani et al. 2021 \\
\hline & India (Polur) & 37 & 34 & 188 & Ravisankar et al. 2016 \\
\hline & Egypt & 45 & 10 & 51 & Shoeib and Thabayneh 2014 \\
\hline & European Union & 45 & 31 & 216 & Trevisi et al. 2012 \\
\hline & Serbia & 37 & 15 & 43 & Pantelić et al. 2015 \\
\hline & Malaysia & 29 & 31 & 205 & Abdullahi et al. 2019 \\
\hline & Bangladesh & 61 & 65 & 952 & Asaduzzaman et al. 2015 \\
\hline & Turkey (Osmaniye) & 64 & 46 & 306 & This study \\
\hline \multirow[t]{5}{*}{ Concrete } & Nigeria & 23 & 60 & 536 & Aladeniyi et al. 2021 \\
\hline & China (Beijing) & 16 & 51 & 605 & Tuo et al. 2020 \\
\hline & Serbia & 17 & 21 & 253 & Kuzmanović et al. 2020 \\
\hline & European Union & 60 & 35 & 392 & Trevisi et al. 2012 \\
\hline & Turkey (Osmaniye) & 46 & 19 & 115 & This study \\
\hline \multirow[t]{8}{*}{ Sand } & Nigeria & 18 & 59 & 236 & Aladeniyi et al. 2021 \\
\hline & Iran (Semnan) & 24 & 22 & 362 & Imani et al. 2021 \\
\hline & India (Polur) & 11 & 130 & 297 & Ravisankar et al. 2016 \\
\hline & Egypt & 17 & 13 & 119 & Shoeib and Thabayneh 2014 \\
\hline & Serbia & 26 & 30 & 210 & Pantelić et al. 2015 \\
\hline & Malaysia & 43 & 45 & 451 & Abdullahi et al. 2019 \\
\hline & Bangladesh & 54 & 77 & 982 & Asaduzzaman et al. 2015 \\
\hline & Turkey (Osmaniye) & 12 & 5 & 90 & This study \\
\hline \multirow[t]{8}{*}{ Clay brick } & Nigeria & 40 & 62 & 1045 & Aladeniyi et al. 2021 \\
\hline & Iran (Semnan) & 31 & 28 & 338 & Imani et al. 2021 \\
\hline & China (Beijing) & 14 & 39 & 678 & Tuo et al. 2020 \\
\hline & Serbia & 45 & 49 & 646 & Kuzmanović et al. 2020 \\
\hline & India (Polur) & 5 & 23 & 374 & Ravisankar et al. 2016 \\
\hline & Egypt & 23 & 23 & 448 & Shoeib and Thabayneh 2014 \\
\hline & Czech & 45 & 47 & 611 & UNSCEAR, 2008 \\
\hline & Turkey (Osmaniye) & 64 & 31 & 372 & This study \\
\hline \multirow[t]{6}{*}{ Marble } & Iran (Semnan) & 7 & 7 & 917 & Imani et al. 2021 \\
\hline & China(Taiwan) & 16 & 22 & 133 & UNSCEAR 2008 \\
\hline & Germany & 24 & 5 & 90 & UNSCEAR 2008 \\
\hline & Greece & 81 & 34 & 483 & UNSCEAR 2008 \\
\hline & Pakistan & 16 & 20 & 248 & UNSCEAR 2008 \\
\hline & Turkey (Osmaniye) & 30 & 58 & 297 & This study \\
\hline \multirow[t]{9}{*}{ Granite } & Nigeria & 74 & 100 & 1098 & Aladeniyi et al. 2021 \\
\hline & Iran (Semnan) & 38 & 47 & 917 & Imani et al. 2021 \\
\hline & China (Beijing) & 356 & 318 & 1637 & Tuo et al. 2020 \\
\hline & Serbia & 200 & 77 & 1280 & Kuzmanović et al. 2020 \\
\hline & Germany & 100 & 120 & 1000 & UNSCEAR 2008 \\
\hline & Italy & 89 & 94 & 1126 & UNSCEAR 2008 \\
\hline & Spain & 86 & 45 & 1028 & UNSCEAR 2008 \\
\hline & Serbia & 38 & 43 & 660 & Pantelić et al. 2015 \\
\hline & Turkey (Osmaniye) & 45 & 82 & 932 & This study \\
\hline \multirow[t]{7}{*}{ Gypsum } & Iran (Semnan) & 12 & 14 & 116 & Imani et al. 2021 \\
\hline & Egypt & 8 & 8 & 85 & Shoeib and Thabayneh 2014 \\
\hline & Czech & 12 & 10 & 187 & UNSCEAR 2008 \\
\hline & Italy & 8 & 3 & 160 & UNSCEAR 2008 \\
\hline & Romania & 41 & 40 & 199 & UNSCEAR 2008 \\
\hline & European Union & 15 & 9 & 91 & Trevisi et al. 2012 \\
\hline & Turkey (Osmaniye) & 45 & 12 & 102 & This study \\
\hline
\end{tabular}

Table 3 


\begin{tabular}{lcccc}
\hline Sample ID & \multicolumn{3}{c}{ I $\mathrm{I}_{\alpha}$} \\
\cline { 2 - 5 } CEM & Average & Range & Average & Range \\
CONC & 0.5 & $0.3-0.7$ & 0.3 & $0.1-0.5$ \\
CBRICK & 0.3 & $0.2-0.4$ & 0.2 & $0.1-0.3$ \\
PBRICK & 0.5 & $0.2-1.0$ & 0.3 & $0.1-0.7$ \\
SND & 0.6 & $0.5-0.7$ & 0.3 & $0.2-0.5$ \\
AGG & 0.10 & $0.06-0.12$ & 0.06 & $0.04-0.10$ \\
MARB & 0.102 & $0.096-0.108$ & 0.043 & $0.037-0.048$ \\
GRNT & 0.49 & $0.02-1.35$ & 0.15 & $0.01-0.45$ \\
CTIL & 0.9 & $0.6-1.4$ & 0.2 & $0.1-0.5$ \\
RTIL & 0.4 & $0.1-0.9$ & 0.2 & $0.1-0.5$ \\
GYP & 0.37 & $0.32-0.45$ & 0.14 & $0.09-0.18$ \\
LSTN & 0.24 & $0.16-0.33$ & 0.22 & $0.13-0.27$ \\
IMAT & 0.21 & $0.18-0.24$ & 0.22 & $0.19-0.25$ \\
GROU & 0.25 & $0.09-0.47$ & 0.26 & $0.09-0.47$ \\
CGLUE & 0.23 & $0.11-0.32$ & 0.19 & $0.08-0.27$ \\
\hline
\end{tabular}

Table 4 


\begin{tabular}{|c|c|c|c|c|}
\hline Sample ID & & $\mathrm{D}_{\mathrm{R}}\left(\mathrm{nGy} \mathrm{h}^{-1}\right)$ & $\mathrm{E}_{\mathrm{R}}\left(\mathrm{mSv}^{-1}\right)$ & ELCR \\
\hline \multirow[t]{2}{*}{ CEM } & Average & 134 & 0.7 & $2.3 \times 10^{-3}$ \\
\hline & Range & $87-168$ & $0.4-0.8$ & $1.5 \times 10^{-3}-2.9 \times 10^{-3}$ \\
\hline \multirow[t]{2}{*}{ CONC } & Average & 73 & 0.4 & $1.3 \times 10^{-3}$ \\
\hline & Range & $44-93$ & $0.2-0.5$ & $7.5 \times 10^{-4}-1.6 \times 10^{-3}$ \\
\hline \multirow[t]{2}{*}{ CBRICK } & Average & 122 & 0.6 & $2.1 \times 10^{-3}$ \\
\hline & Range & $45-261$ & $0.2-1.3$ & $7.7 \times 10^{-4}-4.5 \times 10^{-3}$ \\
\hline \multirow[t]{2}{*}{ PBRICK } & Average & 135 & 0.7 & $2.3 \times 10^{-3}$ \\
\hline & Range & $113-163$ & $0.6-0.8$ & $1.9 \times 10^{-3}-2.8 \times 10^{-3}$ \\
\hline \multirow[t]{2}{*}{ SND } & Average & 24 & 0.12 & $4.1 \times 10^{-4}$ \\
\hline & Range & $16-29$ & $0.08-0.14$ & $2.7 \times 10^{-4}-5.0 \times 10^{-4}$ \\
\hline \multirow[t]{2}{*}{ AGG } & Average & 25 & 0.12 & $4.3 \times 10^{-4}$ \\
\hline & Range & $23-26$ & $0.11-0.13$ & $4.0 \times 10^{-4}-4.5 \times 10^{-4}$ \\
\hline \multirow[t]{2}{*}{ MARB } & Average & 15 & 0.07 & $2.5 \times 10^{-4}$ \\
\hline & Range & $1-41$ & $0.003-0.199$ & $1.2 \times 10^{-5}-7.0 \times 10^{-4}$ \\
\hline \multirow[t]{2}{*}{ GRNT } & Average & 26 & 0.13 & $4.5 \times 10^{-4}$ \\
\hline & Range & $16-42$ & $0.08-0.21$ & $2.8 \times 10^{-4}-7.3 \times 10^{-4}$ \\
\hline \multirow[t]{2}{*}{ CTIL } & Average & 13 & 0.07 & $2.3 \times 10^{-4}$ \\
\hline & Range & $4-29$ & $0.02-0.14$ & $7.1 \times 10^{-5}-5.0 \times 10^{-4}$ \\
\hline
\end{tabular}

Table 5 
Figures
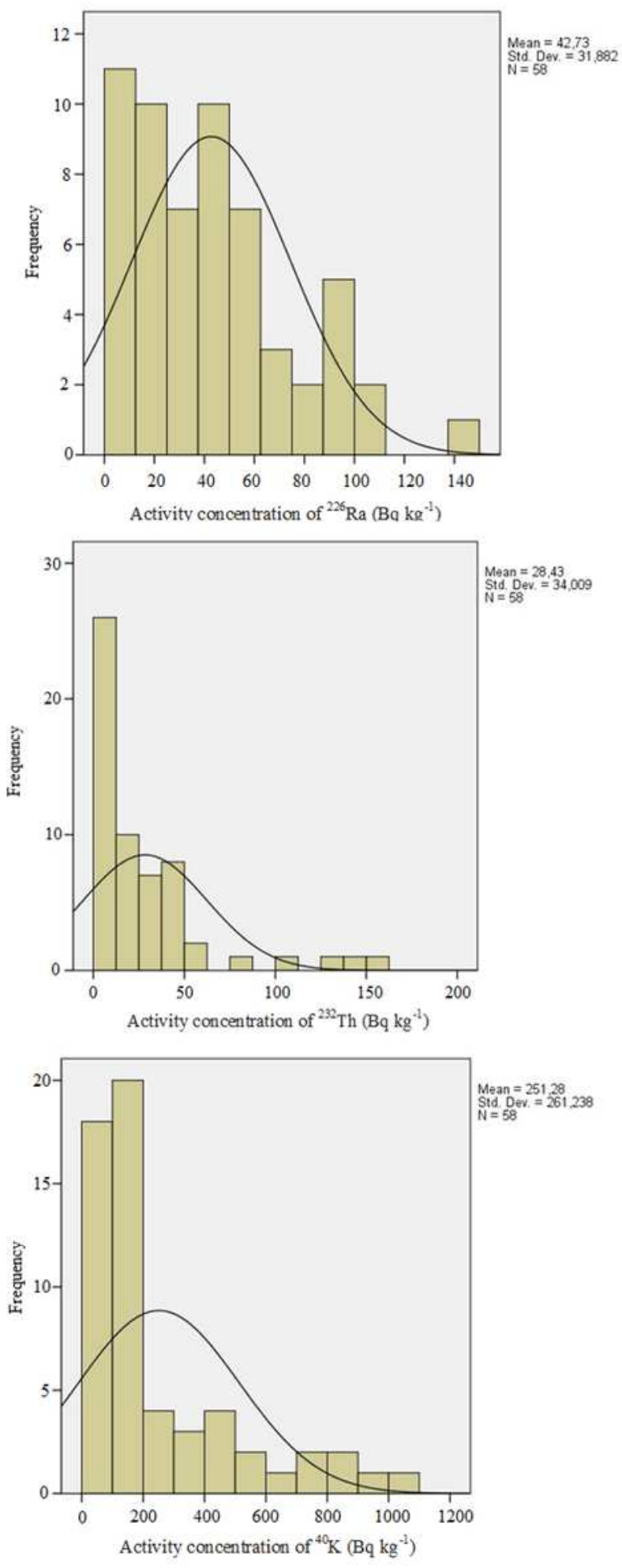

Figure 1

Frequency distributions of the activity concentrations of radionuclides in the studied building materials 


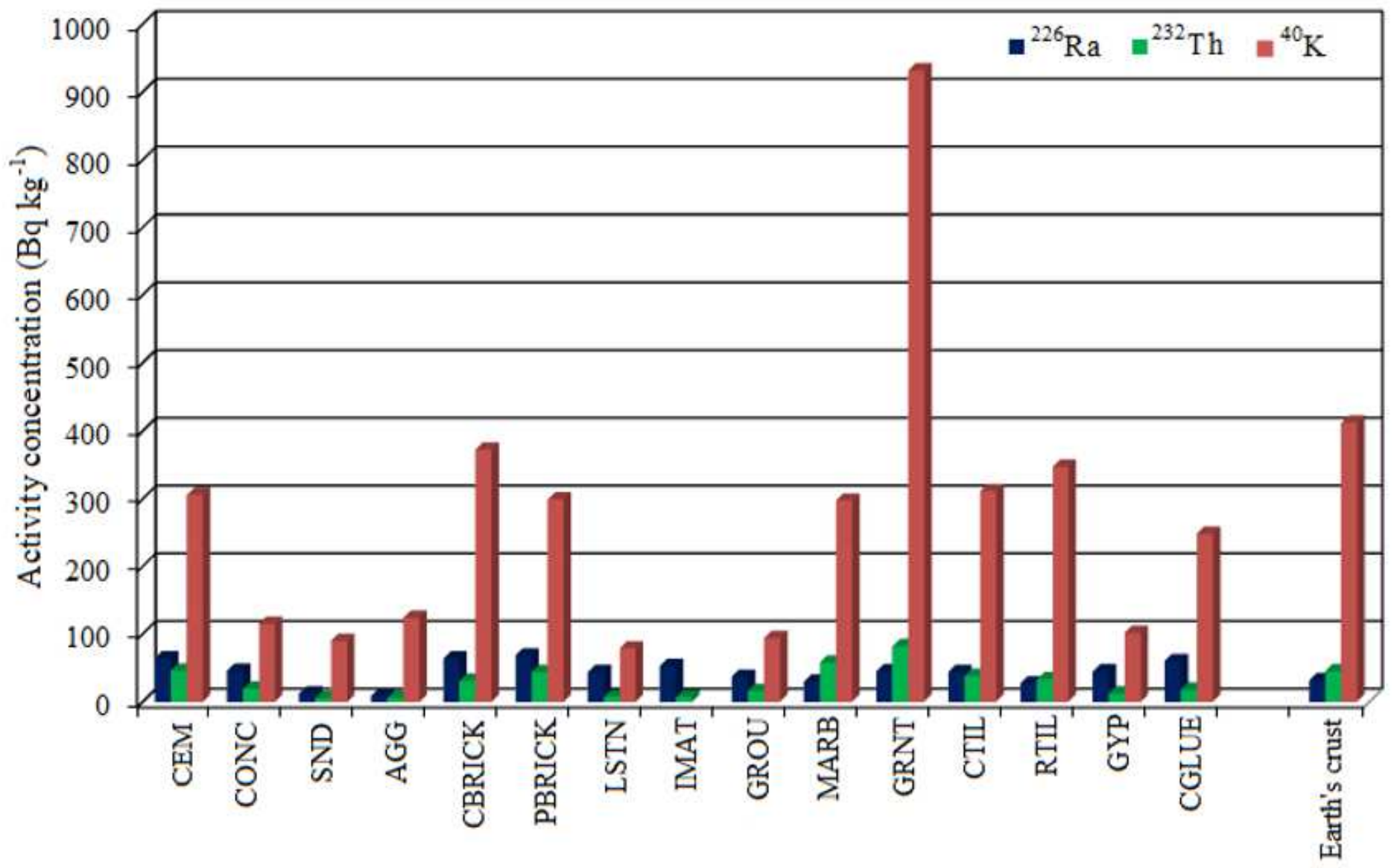

Figure 2

Comparison of the average values of radionuclides measured in the studied building materials with those in the Earth's crust 